\title{
From Rivalry to Nowhere: A Story of Iran-Saudi Ties
}

\author{
Muhammad Rizwan ${ }^{1}$, Muhammad Arshid ${ }^{2,}$ Muhammad Waqar $^{3}$, \\ Saira $\operatorname{Iram}^{4}$ \\ 1, 2, 3, 4 Department of Pakistan Studies/Political Science, Hazara University, Pakistan
}

\begin{abstract}
Almost eighty audacious years of diplomatic ties between Iran and Saudi Arabia witnessed many ups and downs. During these years Iran had faced Islamic (Shia) Revolution (1979) which ended the Pahlavi Dynasty and the established Islamic Democracy under the umbrella of clergy class. On the other side, Saudi Arabia (an Orthodox Sunni state) was ruled by different kings of the Al Saud royal family. Including other factors, differences of Shia-Sunni schools of thought badly affected their mutual ties. Their strain relations had also affected the integrity of the region in one way or the other. In 1980s Saudi-Iran soured liaison had been given a chance to their immediate neighbor Iraq to set the region into war on American indication to get the control of this oil-rich area. Later on Gulf war provided a golden opportunity to US authorities for their permanent presence in the region. American presence in the area enhanced Iran-Saudi Arabia differences. At the present, the effect of their bad relations seems worst than before. Both countries at their utmost boast to the sectarianism in the region to increase their influential area. This approach has also divided the Middle Eastern region into two groups mainly based on different sects of religion Islam.
\end{abstract}

Keywords: Iranian Revolution, Middle East, Monarchy, Shias, Wahhabism,

\section{Introduction}

Iran and Saudi Arabia, two neighboring Muslim countries, occupy important position in the Middle Eastern region. It is an historical birthplace of all major religions of the world including Judaism, Christianity and Islam.[1] History of the region designated the terms Near-East and Middle-East, referring two different regions. The Near East representing the Balkans and the Ottoman Empire, while the Middle East covered Iran, Afghanistan, Turkestan and the Caucasus. However, at the end of First World War (1914-1918) and with the fall of Ottoman Empire, the term Near East lost its validity and the Middle East term was adopted in larger scale in the mid of $19^{\text {th }}$ century. Its geographical location attracts the intruders. Present-day, the region is the key point of the foreign policy of the western world, especially of the United States of America. The boundaries of the Middle East region have been redefined/ changed with the passage of time.

East, Eurocentric and West Asia all these terminologies are now referred by the Middle East region. Most of the countries of the Western Asia are considered as the parts of the Middle East region. So in this reference, this region also shows the West Asian part of the Asia. In the 1990s the new term "Greater Middle East" was used which comprising mostly Muslim regions of the North Africa, Western Asia and Central Asia. But this term was not commonly used.[2]

In the $21^{\text {st }}$ century the west Asian countries and the north east Africa country Egypt are considered as the Middle East region. According Wikipedia there are 18 countries in this region; Egypt is the part of Middle East, while some experts excluded her from the region. After studies the map of the Middle East Sinai Peninsula is shown as the part of the Middle East region. Sinai Peninsula is the territory of the Egypt. So in this manner we can say that if whole Egypt is not the part of the region but due to Sinai Peninsula it is partially the part of the Middle East region.

The total land area of the Middle East region is nearly 3,500,000 square miles $(9,000,000$ square kilometers) with 350 million populations. As compare to the U.S.A territory, its area is slightly smaller than her.[3] Bahrain, Cyprus, Egypt, Iran, Iraq, Israel, Jordan, Kuwait, Lebanon, North Cyprus, Oman, Palestine, Qatar, Saudi Arabia, Syria, Turkey, United Arab Emirates and Yemen all these countries comprising the Middle East region.[4]

On the basis of the geo-graphical characteristics, there are different sub-regions like Persia, Arabian Peninsula, Fertile Crescent and Levant within the Middle East region. These sub-regions further grouped the countries of the Middle East region due to physical location. Each sub-region of the Middle East has its historical and physical importance.

1. Persia: Iran is important for her oil and gas resources. She has boundaries with Central Asia and South Asia regions.

2. Arabian Peninsula: Saudi Arabia, Omen, Yemen, U.A.E, Qatar, Kuwait and Bahrain. All the countries of the Arabian Peninsula are Arabs. This is the world's largest peninsula with 1,200,000 square miles area 
(3,100,000 square kilometers). Its three sides are covered by the water of the Red Sea, Persian Gulf, Gulf of Oman, Gulf of Aden and Arabian Sea. This region is known for the oil reserves on the large scales. Its less than $1 \%$ land is used for agriculture. Greatest spatiality of the Arab Peninsula is that Islam emerged on this peninsula in the $7^{\text {th }}$ century. It has sacred Muslim places. The GCC (Gulf Cooperation Council) is the regional organization which refers six countries of the Arabian Peninsula. Yemen is not the member of GCC.

3. Fertile Crescent: Iraq, Syria, Lebanon, Jordan, Palestine and Israel. The archeologist James Henry Breasted had introduced the term fertile crescent on the basis of its physical shape like crescent which has fertile soil and major water source. Its physical location depicts that it connects the three continents (Asia, Africa and Europe) of the world.

4. Levant: its means "where the sun rises" or "where the land rises out of the sea". Levant referred those countries which are situated on the eastern shore of the Mediterranean Sea. Cyprus, Israel, Palestine, Jordan, Syria, Lebanon and southern part of turkey are the countries of the Levant region.

Arab is the largest ethnic group of the Middle East region. Except Iran, Turkey and Israel rest of all the countries of the region are Arabs.

"Various concepts are often being paralleled to Middle East, most notably Near East, Fertile Crescent and the Levant. Near East, Levant and Fertile Crescent are geographic concepts, which refer to large sections of the modern defined Middle East, with Near East being the closest to Middle East in its geographic meaning."[5] The geo-graphical features of the Middle East region has explained its four major characteristics due to which this region has become the source of attention for the rest of the world.

1. Oil reserves

2. International water path

3. Location

4. Religious facts

- In the mid of the 20th century the oil reserves in large scales has been discovered in this region. Middle East region has some $2 / 3$ of the world's oil reserves which show the vital significant of the region for the world's economic development. This region is the main focus of the developed countries and their interests relate to this region. Due to the natural oil and gas reserve this region dominates in the international oil cartel OPEC (Organization of the Petroleum Exporting Countries).

- $\quad$ The world largest trade is done through sea. So to have a coastal with sea is considers as a blessing for a country because this added the geo strategy importance of a country in the region. The different countries of this region have their coastal with major different seas. Iran has her coast with Caspian Sea and Persian Gulf. Arabian Peninsula is covered be Red Sea, Persian Gulf and Indian Sea. Turkey have her coastal with Black Sea, Aegean Sea and Mediterranean Sea. The Levant countries are situated on the Mediterranean Sea. In this way the region has seven major seas which give international water path for the world trade. Suez Canal connects the Mediterranean Sea to the Red sea which provides the easiest and shortest passage to the European countries toward red sea. This facilitates their sea trade with the South African countries and different regions of the Continent Asia.

- The boundaries of Middle East region have adjunct with Europe in north, in east with Central Asia and South Asia and in southwest with Africa. In this order it is the only specialty of this region that having land access with two continents (Europe and Africa) and itself is the region of Asia that is the world's largest continent by area and population.

- This region is highly known for the Israel Arab conflict or Israel Palestine conflict. Israel is the only world's Jewish state that is situated in the Middle East region. This is important for Judaism, Christianity and Islam as their religious history and scared religious places belong to this region.

The significant of this research work is to highlight that how the hostile relation of the Iran and Saudi Arabia is weakening the integrity of the region and strengthen the western interests toward this region and would be the affect of their good relation on the Middle East region.

\section{From Antiquity to Present: Saudi-Iran relationship}

In the East of the Middle East region Iran is situated while Saudi Arabia is in Arabian Peninsula of the Middle East region. Both countries belong to the one region but having no boarder with each other. In the east of the Saudi Arabia across the Persian Gulf is Iran. Both represent two sub-regions (Persia and Arabian Peninsula) of the Middle East. Before having the view of their diplomatic relations, it is necessary to explain the location of the both countries which distinguish their regional importance.

\subsection{Saudi Arabia}

Saudi Arabia has 2,149,690 square kilometer (829,995 square mile) land area which has boarders with 8 Middle Eastern countries including Iraq, Kuwait, Jordan, Qatar, Bahrain, Omen, Yemen, and U.A.E. In west, it has coastal with Red Sea and the Gulf of Aqaba and in east with Persian Gulf. It is not only the largest country 
of the Arabian Peninsula by land but also the largest country of the Middle East region. The first Islamic state in the world under the leadership of the Prophet Hazrat Muhammad (P.B.U.H) was founded in the westen part of the present Saudi Arabia in $7^{\text {th }}$ century. Mecca always remained sacred place in the ancient, medieval and modern times.

Hejaz and Nejd both are important regions of the Saudi Arabia because of their physical location, religious, culture and history. West part of the Saudi Arabia is called Hejaz along the Red Sea and the east part of the Saudi Arabia is Nejd the central part of the Saudi Arabia. In different time period of the history both regions were separately ruled and usurped by different empires. Nejd is known for mountains, vast oasis and having the capital city Riyadh while Hejaz has the sacred Muslims places (Mecca and Medina).

In the mid of the eighteenth century, the Wahhabi reforms have started in the Nejd region. This region was ruled by al Rashid and Al-Saud family. By the end of the nineteenth century the Nejd was ruled by the Al Saud family with Wahhabi authority. On other side, Hejaz was ruled by caliphs, Egypt, Ottoman and after the World War I Sharif of Mecca got the control of Hejaz. In 1925, Abdul Aziz of the Al Saud family, ruler of the Nejd, defeated the Sharif of Mecca and captured the Hejaz. Both regions were ruled by him separately till 1932, when he unified the Al Hasa, Qatif, Asir, Nejd and Hejaz with the name of the Kingdom of the Saudi Arabia. From that day onwards, except few minor reforms in 2005 the system continued to propagate Wahhabism in its extreme form and presence of largest oil reserves helped a lot to achieve the said objectives up to great extend.

\subsection{Iran}

Iran, the $2^{\text {nd }}$ largest country of the Middle Eastern region with an area of 1,648,195 square kilometer (636,372 square mile) having six neighboring countries of the different regions i.e., two countries of Middle East (Turkey and Iraq), two countries of the Central Asia (Azerbaijan and Turkmenistan) and two countries of the South Asia (Pakistan and Afghanistan). However, in its north the Caspian Sea and in south Persian Gulf and Gulf of Oman are enhancing its importance.

Different ancient civilizations flourished on the land of Persia. Elamite Kingdom (625 BCE), Achaemenid Empire (550 BCE), Sassanian Dynasty (224 CE) are the most remarkable civilizations depicting the glory of the land. During the $7^{\text {th }}$ century, Iranians were introduced by Islamic culture and belief with the invasion of Umayyad and Abbasid caliphs. Yet, in the sixteenth century the Safavid dynasty was emerged and the Twelver school of thought was accepted as the official religion of the state. The constitutional monarchy was established with the Persian Constitutional Revolution of 1906 but soon the Iranian government becomes autocrat under the influence of United Kingdom. However, during 1925, the Pahlavi dynasty took over the control of the Iran which ultimately ended with the rise of Islamic Revolution in 1979 bestowing the status of Iran as an Islamic Republic. Within no time all major Muslim dynasties of the region including Saudi Arabia considered this "Shia dominating revolution" as a major threat to their survival. Yet, geographical significance of the country obligated these forces to avoid face to face clash with Iran. In point of fact, Iranian reserves ranked on $2^{\text {nd }}$ largest in the Middle Eastern region and largest natural gas reserves in the world intensified its geographical importance.

"A geographically diverse but mostly mountainous country, Iran has always been of significant geopolitical importance, owing to its location at the crossroads of Central Asia, Western Asia, and South Asia”.[6]

In the beginning of the nineteenth century, discovery of oil reserves in Iran attracted the attention of major powers of the world including UK, USA and Russia etc. In the field of exporting oil, it is third largest country of the globe. Being the member of the different international, regional and economic organizations, it, like Saudi Arabia, has distinguished place among their member's countries.

\section{Fundamental Driver of the Relationship}

The diplomatic relations of Iran and Saudi Arabia has completed almost 78 years of existence, which are full of swings. During these years, Iran had faced an Islamic Revolution of 1979 leading it towards the Islamic democracy. It closed the chapter of the dynasty on the land of Iran. On other hand, Saudi Arabia has been ruled by the different kings of the Al Saud royal family who, except the mild political reforms in 2005, gave little space in their absolute monarchy.

Iran and Saudi Arabia relations can be studied into two major phases.

- The first phase covered the time period before the Islamic Revolution of Iran (1929-1979).

- The $2^{\text {nd }}$ phase has the post time period of the Islamic Revolution of Iran (1979-present).

\subsection{Relation of both countries in first phase (1929-1979)}

The diplomatic relationship between Iran and Saudi Arabia had been started in 1929 with the promulgation of Saudi-Iranian Friendship Treaty. However, after the Saudi-Iranian Friendship Treaty, no major development had been seen between their relations till in the beginning of 1960s. In reality, both governments 
were busy in developing their own country's infrastructures. Interestingly, both monarchies had achieved wide control of their countries in 1925; as in this year the Pahlavi Dynasty was established in Iran and Al Saud family ousted the Sharif from the Hejaz. So in first decade both were working on the establishment oh their government and development of the country. From 1929 to 1968, many international and regional events took place which affected their foreign police. However, on World War II, establishment of the Israel, Arab-Israel wars, impacts of Cold War era, concluding of Defense Treaties etc Iran and Saudi Arabia followed opposite policies against each other.

In this phase both countries had faced the $2^{\text {nd }}$ World War (1939-1945). As this war was fought between Allies headed by UK and Axis this was headed by Germany. In this war both governments of the Iran and Saudi Arabia remained neutral status, however, because of the geo-political importance of the Iran and Shah's close ties with Germans, the British and Russian armies attacked on Iran from west and north sides without giving any ultimatum. In order to get the control of the Iranian oil reserves, its neutrality was not accepted.

As expected, Shah of Iran (Raza Shah) was defeated by the Allies and a large part of the Iran went to the control of the Russia and British during the World War II. After the World War II, Raza Shah was replaced by his son Muhammad Raza Shah under the foreign pressure. So the World War II was resulted of vast devastation of the Iran's infrastructure.

On the side, the Saudi Arabia, in the beginning of the World War II had maintained its neutral policy. But because of the Abdul Aziz's inclination toward the American President Franklin Roosevelt, they could not continues their neutral position by supplied the oil to the Allies against the Germany's Army. Yet Saudi Arabia had not bearded any type of penalty and devastation in the World War II. Consequently, Saudi Arabia remained more save and sound than the Imperial state of the Iran.

After the World War II as compared to British the American influence was more increased in the Middle East region. The result of the World War II had started the cold war era between Russia and America. For having the honors of World Super Power, they had to increase their influential circle with strongest position in the political and policy maker department of the countries of the different region.

Because of the three attributes of the Middle East region, this was the key of attraction for the both parties of the cold war era.

1. Geo-graphical location of the region

2. Black gold means crude oil reserves

3. Establishment of the Jewish state Israel

The geographical location of the whole Middle East region is, no doubt, important but the Iran's geo location is significant. Even in the past it had boarders with south Asia (Pakistan and Afghanistan) and with central Asia at that time this region was the part of Russia. With the feature of the larger crude oil reserves it had the direct land link with the Russia. During the World War II, Russian-Iran relations contradicted and the western powers took the advantage of the situation by enhancing ties with the Shah of Iran against the Russia. Similarly, in 1948 when first Jewish state of Israel was established in the Middle Eastern region it magnified its significance for the western powers.

"In the 1950s, the Middle Eastern region was dominated by four different but overlapping struggles, each distinct from the other, but linked in various ways. The first was the geopolitical struggle for influence between the United States and the Soviet Union known as the Cold War. The second was the struggle between various Arab nationalists against the two remaining imperial powers, Britain and France. The third was the Arab-Israeli dispute, and the fourth was the struggle between different Arab states for the leadership of the Arab world, known as the Arab Cold War." [7]

\subsection{Defense pact 1955}

During the Cold War period two blocs, western and the Communist bloc came into existence. Member's countries of the western bloc comprised alliance by signing the NATO in 1949. In the response, Russian and the Communist nations of the Eastern Europe had signed WARSA Pact in 1955.

"The alignment of nearly every European nation into one of the two opposing camps formalized the political division of the European continent that had taken place since World War II (1939-45). This alignment provided the framework for the military standoff that continued throughout the Cold War (1945-91)." [8]

Western bloc was highly active with the message that communist USSR's expansion policies are the threat for the newly independent states of the different regions. In the history two defense treaties were signed against the USSR, those known as SEATO and CENTO. The focus was Middle East and South East Asia regions, to limit the communist influence from those regions.

America and Britain wanted a treaty of the Middle East countries against the Russian communist block. But the Egypt under Gamal Abdul Nasser rejected any alliance which was not headed by the Egypt. Issues with British government on the Israel formation, Suez Canal and its colonial policies encouraged the Egypt toward 
the USSR. So the nationalist government refused to accept the Soviet as the threat to its integrity as USA government was tried to convince its. So in 1955 the Baghdad Pact was signed by the three Middle East countries Iran, Iraq, Turkey along Pakistan and Britain.

"Britain's close relationship with the two Hashemite kingdoms of Iraq and Jordan were of particular concern to Nasser. In particular, Iraq's increasingly amicable relations with Britain were a threat to Nasser's desire to see Egypt as head of the Arab world. The creation of the Baghdad Pact in 1955 seemed to confirm Nasser's fears that Britain was attempting to draw the Eastern Arab World into a bloc centered upon Iraq, and sympathetic to Britain."[9]

Saudi Arabia also disliked the CENTO Pact. Its concern was same of the Egypt Nationalist government. Hashemite-dominated pact was opposed by Saudi Arabia's king.

"America's closest Arab ally, Saudi Arabia, was just as fundamentally opposed to the Hashemitedominated Baghdad Pact as Egypt, and the U.S. was keen to increase its own influence in the region" [10]

\subsection{Suez Canal Crisis 1956}

The crisis was started over the contention of Suez Canal control among Egypt, British and France. Suez Canal meets the Mediterranean Sea to the Red Sea. In response to Egypt's government action to take Suez Canal under the national control, in 1956 British, France and Israel forces encroached the Egypt to strengthen their influence in Egypt, get the control of the Suez Canal and usurped the Nasser's Nationalist government, which would be threaten the western interest toward the region.

British, France and Israel military action against the Egypt was condemned by the Arab countries, international community and even USA government was not in favor of their military action against the Egypt. Due to this war Soviet got the chance to increase its influence in Egypt against the British. Saudi Arabia had strongly condemned their aggressive action and ended the oil supply to the Britain and France.

\subsection{Arabs Israel Conflict}

There was a vital role of the British government to settle a homeland for the world's Jewish with the Zionism Movement. The ideological conflict and aggressive and expansion attitude of the Israeli government, it erupted the turmoil in the Middle East region which caused many Arab Israel Wars. In 1956 Suez War Israel subjugated the Gaza, West Bank and Sinai Peninsula, this intensify the Arab Israel Conflict. Arabs countries were at the stake while Iran's Shah had established diplomatic relations with Israel. In 1950s Israel was consider a great threat for the Arabs. It was admitted by the USA government.

"It was a source of constant puzzlement to American officials in the 1950s that the Arab states and the Israelis had seemed to have more interest in fighting each other rather than uniting against the Soviet Union.”[11]

Point of view of the Saudi Arabia and Iran's Shah toward these international and regional disputes were different but the relations of the both countries were cold rather than deteriorated.

In 1960s the Iran gained economic and military dominance in the Middle East region, being the member of defense treaties and western ally. Iran's Shah had respectable influence on regional level and played the role of meditate in the Pakistan and Afghanistan disputes.

In 1958 army coup in Iraq had abolished the monarchy with the desire of becoming the part of the U.A.R (United Arabs Republic). But it had encouraged the political insurgent as Kurd and Iraqi nationalists were at the opponent with others. In last 1960s, the Gamal Abdul Nasser's government was gone weak in Egypt, after his death in 1970, he replaced by Anwar Sadat. Due to the resentment with Soviet and defeat in 1973 war with Israel for the Sinai Peninsula, Egypt had lost its dominance in the region. U.K vacated the Persian Gulf. After the 1967 six days war, the Iranian public rejected the friendly relations with Israel in the preference of the Muslim brotherhood. Saudi Arabia under the kingship of the King Faisal got significant place among the Muslim world.

So Saudi Arabia and Iran were emerged as two strong parties for the peace and security in the region. It was the requirement of the both countries of mutual work. In this situation the official visits of the both kings strengthen their relations in 1966. In 1968 a demarcation agreement was signed between them. King Faisal struggles for the Islamic solidarity and establishment of the OIC were encouraged by the shah. Saudi Arabia had played its political role in regional and international disputes and forums. In 1973 Saudi Arabia participated in the Arab Oil Boycott and stopped the oil supply to America and France. It was a reaction against the Arab Israel war 1973.

In 1975 King Faisal was assassinated and King Khalid replaced him. On other side Shah's White Revolution, socioeconomic advancement, pro-western, autocracy and secularism had made a large part of the country against him. So under the Khomeini Islamic Revolution deposed the Pahlavi dynasty in Iran and Islamic Republic of Iran came forward with the new political, religion, regional and international approaches. 


\section{Iran and Saudi Arabia Relation in Post-Islamic Revolution Period (1979-present)}

$2^{\text {nd }}$ phase comprising almost 33 years of the relations in which two decades depicts both countries the opponents of the Middle East region. In 1979 the Islamic Revolution of the Iran had revised the all systems of the Iran. After the revolution, she got major changes like,

1. Iran had changed its status; its revolutionary government declared its as the Islamic Republic of Iran and Imperial State of Iran was changed.

2. Anti western policies were demonstrated. The revolutionary government had rejected the Shah's prowestern policies. New government had openly condemned the aggressive policies of the USA in the Middle East region. Israeli's expansion policies in the Palestine were taken as a threat to the Muslim Umma. They revised the western moderation of the Shah with the Islamic traditions and culture.

3. Anti-monarchy policy was adopted by the spiritual leader Khomeini. According him there is no concept of monarchy in Islam. In this sense he challenged the legitimacy of the monarchy, which was ruled in most of the Arabs countries.

4. Shiite (Shia) beliefs were own by the revolution government. Iran is one of those countries of the region which has Shia majority. In Pahlavi dynasty, Muhammad Raza Shah had adopted the secularism attitude and his focus was on the advancement and western moderations in Iran. But after the Islamic revolution, Iran came in the region with Shiite school of thought. This was (is) a concern for the Wahhabi authority of the Al Saud kingdom.

On other hand the Arab countries had espoused the rapprochement policies toward the Israel after defeated by the Israel in many Arab Israel wars. The USA influence in the Arab countries was increased. Most of the Arab countries were ruled by the royal families. So in this geo-strategic Middle East the Islamic Republic of Iran with anti western, anti monarchy and Shiites School of beliefs, was considered a threat for the region in future.

After the revolution the factor which deteriorated the Iran Saudi Arabia relation was the remarks of the Iranian spiritual leader Khomeini. Islamic Revolution was the reaction of Shah's pro western policies, so the Khomeini embraced the oppressive policies toward the USA. Saudi Arabia was considered a firm partner in the region so she also became the victim of his oppressive policies toward USA.

According him that Saudi Arabia is destroying the regional integrity and completing the USA interests in the region. As in those days, Saudi Arabia was the front line state of the USA in the fighting against Russian invaded army in Afghanistan in 1979. Saudi Arabia's support to Saddam Husain's expansion action against the Iran and the Hajj Incident 1987, these made him angry with the Saudi Kingdom.

"In a 1987 public address Khomeini declared that "these vile and ungodly Wahhabis, are like daggers which have always pierced the heart of the Muslims from the back," and announced that Mecca was in the hands of "a band of heretics".'[12]

The aggressive policies of the revolutionary government had isolated its from the regional and international community. The Saddam Hussein with Arab Nationalist view took the new Iran weak party as compared to the Shah's Iran. For regaining the Shatt al Arab and the oil-rich Iranian Province Khuzestan, his army attacked the Iran in 1980. In Iran history this war is known as "Imposed War". The Saddam wanted to become the leader of the Arab world and to have the dominance over the Persian Gulf.

Due to the Iranian leader Khomeini's discriminated remarks toward the Saudi Kingdom, in this IranIraq War Saudi Arabia was obvious at the side of Iraq although at that time she had not good relations with Iraq.

"The Iran-Iraq War increased Saudi concern about their security, leading to their financial support to Iraq, although the relations between Iraq and Saudi Arabia at that time were not warm. Therefore, the reason for helping Iraq was that Saudi Arabia recognized that revolutionary Iran was a far greater threat to its survival and the stability of the region." [13]

She gave US\$25 billion of aid to Iraq in Iran Iraq war (1980-88). She also launched a Media War against the Iran to demoralize the Iran on regional and international levels. Not only this, she convinced the Arab countries of the Persian Gulf to put their strength on the side of Iraq against Iran. Syria was the only supporting country in the Middle East region. With such isolator situation, Iran never gave up in the longest conventional war in the $20^{\text {th }}$ century. This war ended in 1988 after 7 years, 10 months, 4 weeks and 1 day with the effort of the UNO.

On one side Iranian were busy to defend their country against Iraq invasion, on other side the Hajj Incident 1987 was happened in Mecca. In this incident 400 people in which 275 Iranian were included died in the clashed with Saudi Forces and Saudi government prohibited on all Hajj rituals. In response in Tehran Saudi Embassy and diplomats were attacked by the oppressive Iranian crowd which result one Saudi official died due to serious injuries. These events badly affect the relation of the both countries and Saudi Arabia had broken its diplomatic relation with Iran, which restored in 1991.

After the Iran-Iraq war, leadership of the both countries King Fahd and Iranian President felt the need to improve their relations. Iraq Kuwait front gave the message that their good relations are necessary for the 
integrity of the region. Official reciprocal visits had been taken to strengthen the official ties between two countries. Iranian was allowed to attend the Hajj (pilgrimage) with the increased pilgrim's quotas. The relations of the both countries were regulated slowly.

In 1996 Khobar Towers bombing in Saudi Arabia in which USA's army were died and injured. USA blamed to Iran for this bomb explosion but Saudi government did not strain its relations with Iran. In 1997 Arab's leaders had attended the meeting of the OIC which was held in Iran. This gave the signal of the improved relations of the Iran with the Arab countries of the region.

The first visit of any Iranian President after the revolution was taken by the President Muhammad Khattami to Saudi Arabia in 1998. In which the main Iranian concerns toward Saudi Arabia and its mutual cooperation between both countries were discussed related regional and OPEC's producing quotas. The Saudi Arabia gave positive response to Iranian president's concerns.

In the same year A Comprehensive Co-operation Agreement paved their relations not only the political but also in cultural and sport fields. In 2001 Saudi-Iranian security Agreement was signed, the Iran Nuclear programmed was supported by the Saudi government.

This improved relations were once again became hostile due to the Iranian President AhmediNajad aggressive policies toward America, Israel, Nuclear programmed and supporting to the Hezbollah in Lebanon, Hamas in Palestine, Houthis in Yemen. These are the Shia insurgents groups, in which two are fighting against Israel and Houthis fighting civil war against their royal government.

In Israel Hamas conflict Iran was stand for the rights of the Palestine's and urged to the Arab countries to cut their relations with Israel. Iranian president's remarks against the Arabs and Saudi Arabia were disliked and taken the Iran as an opponent by the Saudi kingdom.

"Iranian President Ahmadinejad strongly condemns Israeli attack on Gaza and put pressure on Arab and other Muslim countries to help Hamas. Iranian President, Ahmadinejad urged King Abdullah of Saudi Arabia to speak out against Israel's attack on Gaza. He also accused the Saudi King and other leaders of Arab countries of being complicit in"genocide" perpetrated against the Palestinians. Therefore, he stressed all the Arab countries to cut their ties with Israel." [14]

The Saudi leadership had started the hostile policies against Iran and provoked its threat for the peace and stability of the region because of its nuclear programmed. It accused that Iranian government is meddling in the internal affairs of the Yemen and Bahrain.

Sa'dah war was fought between Yemen government and the Shia insurgents who called Houthis. Saudi Arabia provided military support to Yemen's government against the Shia insurgent group. The comments of the leadership of the Iran and Saudi Arabia regards de-stability of the Yemen soured the relations.

"Iran has heavily criticized Saudi Arabia for their intervention in the Sa'dah War between Yemen's government and Shi'a insurgents. Iranian President Ahmadinejad was quoted as saying: "Saudi Arabia was expected to mediate in Yemen's internal conflict as an older brother and restore peace to the Muslim states, rather than launching military strike[s] and pounding bombs on Muslim civilians in the north of Yemen," while Saudi Foreign Minister Saud Al Faisal accused Iran of meddling in Yemen's internal affairs.”[15]

According Wiki leaks, Saudi king was urged USA to take strong action against Iranian nuclear programmed rather than sanctions because sanctions are not providing affected pressure on Iranian government? The reaction of the Saudi Arabia's leadership was highly concerned towards the Iranian Nuclear programmed in the region. All these activities of the both countries had intensified the relations and the environment of the Middle East region. This unrest situation had lead to expend Saudi Arabia highest percentage of GDP on the development of military.

"In 2012 Middle Eastern countries accumulated more than $\$ 132$ billion in military spending, the highest percentage of GDP in the world (with Saudi leading at 8.9 per cent of GDP, Oman 8.4 per cent and Israel 6.2 per cent)."[16]

The Arabs spring in the Libya, Egypt, Tunis, uprising in Syria and the new Shia government in Iraq after the Saddam regime all changes in the region had been noticed and examined by the Saudi's kingdom that it would lead the Iran in the Middle East region.

Hassan Rouhani became the Iranian president after the presidential election in August 2013, which leads the Iran into the rapprochement direction with western countries. So the Iran signed Geneva Agreement with six powers (P5+I) America, Britain, China, Russia, France and Germany on its Nuclear programmed and to get suspension of the international sanctions. This development is appreciated by the world; this will further relax the Saudi Arabia's concern on the Iranian Nuclear programmed. Saudi Arabia government gave positive response towards the new Iranian government. But there is still lack of confident measures between their relations. 


\section{Concerns of the Both Governments}

After studies and analysis the history of the Saudi Arabia and Iran relations, there were (are) few concerns expressed by the both sides; those caused for the unrest, mistrust and intense relations. For having the impartial conclusion, it is necessary to discuss the concerns of both rivals of the Middle East region.

In first phase of the relations the features of the Imperial state of Iran were

1. Western moderation

2. Pro-western policies

3. Monarchy ruled by Pahlavi dynasty

4. Military dominance in the region

In first phase two things were common between them. (1) Monarchy (2) oil reserves were discovered in the Persian Gulf region of the both countries. To some extend the pro-western policies was common as Saudi King Abdul Aziz had a dense relation with America, as in World ar II, Saudi Arabia was on the side of Allies and American firm had discovered the oil reserves in Saudi Arabia in 1938. After the death of the Abdul Aziz 1953, the successor kings, due to Suez Canal war 1956, backing the Israel, CENTO Pact and under the influence of the Arab Nationalist had changed their pro-western policies.

\subsection{Saudi's Concerns in First Phase of Relations}

a. Iran's friendly relations towards Israel: After the foundation of the Israel, in 1950 Iran's Shah had started diplomatic relation with Israel along its de facto recognition. In the Middle East region, Jewish in largest number lived in Iran.

"Due to the close ties between the two governments, Iranians tended to associate Israel with projects like the rebuilding of Qazvin after the earthquake in 1962 rather than with the notoriously brutal Iranian secret police SAVAK, which the Israeli Moss ad helped establish and train.”[17]

The intellectuals and elites of the both countries had closed ties. But after the Six Days War of Arabs and Israel, the people of Iran had changed their attitude toward Israel and they severed their diplomatic relation with it.

b. Pro-western policies: in the Shah regime the Iran was the firm partner of the America in the region. The Shah's White Revolution with western advancement was a picture to show the western's affiliation. Shah was with America and Britain in the coup against Mossadagh government, he was punished for nationalizing the Iranian oil reserves. Being the member of the two defense treaties (SEATO and CENTO) Iran was the ally of the western blocked. So there was Saudi's concern over the Iran ally of western, as CENTO and colonial policies of the west were rejected by the Arabs countries.

c. Military dominance: being the member of the defense treaties, Iran got advancement in military techniques and arms. At that time Iran's military became the fifth world army. This military advancement was considered a threat to the stability and security of the region. As Iran claimed on greater Tunb and lesser Tunb, raised dispute between Iran and UAE. Iranian supports to the Shia community in Iraq which started civil war between government and Iraqi Kurds. All these Iranian involvements in region had strengthened the Saudi concern over the military dominance Iran.

\subsection{Concerns of Both Governments in $2^{\text {nd }}$ Phase}

In $2^{\text {nd }}$ phase Pahlavi dynasty was ended with the Islamic Revolution of Iran. So Iran had started its relation as an Islamic Republic with Saudi Kingdom. Iran started with revolutionary policies toward regional and international community while Saudi Arabia's policies toward regional and international community were also changed. In this phase both governments had expressed their concerns over each other different policies like,

\section{Iranian concerns toward Saudi Arabia}

a. Pro-western policies of Saudi Arabia: the criticism of the Iranian Revolutionary government to Saudi Arabia and America, this made closer to each other. From 1979 to present Saudi Arabia seem found of friendly relation with America in the region. Saudi Arabia has American air base on its territory. Saudi connection with Israel is the evidence to follow and projecting the policy and agenda of the USA.

"Iran, which after the Islamic Revolution strictly followed an anti-US policy, always deemed Saudi Arabia as an agent of the US in the Persian Gulf region that speaks for the US interests."[18]

b. Regional security issue: from the Gulf war 1991 the American forces are present for the protection of the region. Iranian government had concerned over the presence of the foreigner forces. Iran wanted that Persian Gulf should be free from the foreigner forces; the regional countries must take the responsibility of the regional security. 
c. Iranian quota in OPEC: after the war with Iraq, it damaged the economic infrastructure on large scale. So Iran was demanded that OPEC (Organization of the Petroleum Exporting Countries) should reallocate the producing quotas, rise in the oil price and wanted Saudi Arabia's favor that the Iranian Infrastructure would allow to export it to Central Asia.

\section{Saudi's concern toward the Iran}

a. Revolutionary government: the first Saudi's concern toward Iran was its revolutionary government. First the revolutionary Iranian government sat inspiration for the insurgent groups in the region toward revolution. $2^{\text {nd }}$ the remarks against the legitimacy of the monarchy in Islam. So Iran was considered as a threat to the stability of the Saudi Kingdom.

b. Nuclear programmed: the Iranian Nuclear programmed is not acceptable for Saudi Arabia. As nuclear development would enhance the importance of Iran and become the cause of Iranian supremacy and dominance in the Middle East region.

c. Funding the regional militant groups: in $21^{\text {st }}$ century the Saudi's concern toward Iran is this that Iran is trying to increase its influential circle by funding the rebel groups against their government. Caused to destabilize the peace of the region. In this way Iran has adopted the policy of meddling the internal affair and disputes of the regional countries like in Yemen and Bahrain.

\section{Affects of the strain relations of the Iran and Saudi Arabia}

Their deteriorated relations have badly affected the interest and the geo-strategic importance of the Middle East region. The affects are as under

\subsection{Distort the peace of the region}

Middle East region become the region of warfare. First Arabs and Israel wars were the cause of the unrest in the region. Than region had faced the two Gulf Wars; Iran-Iraq war which was started by the Iraqi government Saddam Hussein, Saudi Arabia and USA supported to Iraq which extend this war to almost 8 years. In order to give lesson to the revolutionary Iranian Government, it suffered the regional peace too.

$2^{\text {nd }}$ Persian Gulf War was the aftermath of the first one in which Saddam's encroachment in the Iran was encouraged by the Arabian countries. So the Middle East region faced more than one decade warfare which resulted unrest, fear, turmoil and devastation of infrastructure on large scale.

\subsection{Damage the Integrity of the Region}

The desire to become the leader and to have the hegemony over the region, this damaged the integrity of the region. In first decade of deteriorated relations of the both countries Iran was isolated, had no support from the whole region except Syria.

But in the $2^{\text {nd }}$ decade of the soured relation whole region is seen divided on the side of Iran and Saudi Arabia. The Arabian Peninsula has its own GCC founded in 1981, which is dominated by the Saudi Arabia while Iran spreading its influential circle in the Fertile Crescent region (Syria, Lebanon, Palestine and present Iraq).

This division has been propagated on the base of sectarianism that is dangerous for the integrity of region. As sects are more sensitive area, if this element would be projected negative by the developed countries, the Middle East would divide into two blocks and the affect would not be limited to the region, it would definitely affecting the other Muslim countries of the different region on the Sunni and Shia base. So it is a terrible threat to the unity of the Muslims Ummah.

\subsection{Encouraged USA involvement}

In the Middle East region USA always has a space due to the Iran-Saudi Arabia strain relation. In first phase Iran had the strong USA influence which was objectionable for the Saudi Arabia government. Than after the Islamic Revolution of Iran, USA had a friendly hand of the Saudi Arabia.

In Iran-Iraq war, Iraq-Kuwait war, attacked on Iraq, Iranian Nuclear Programmed, Israel Palestine dispute and uprising in Syria there was (is) USA seen as a party. After the Gulf war Iraq-Kuwait, there is USA air base in the Saudi Arabia for the protection of the sacred places. The Saudi Kingdom is always seen dependent on USA for the protection of the Saudi Kingdom and the Saudi Arabia's dominance place in the Muslim world.

\subsection{Sectarianism}

Their offensive relations had started the discussion of Shia-Sunni, Shia-Wahhabi rivalry. It highlighted the sectarianism in the region. This element is highly used by the western media and countries to propagate it as 
the only cause of the confrontation of the Iran and Saudi Arabia. This is also expressed by the Saudi government that the dominant Shia Iran is a threat not only for its but also for the stability of the region.

Such discriminated attitude of the Saudi Kingdom promoted the Iran-Saudi influential game as the Shia-Sunni conflict.

\subsection{Damage the Economy of the Region}

It is proved that war not only affect the parties of the war but also badly affected the peace and economy of the region. So the war period in the Middle East region not only affected the economy of the fighting countries but it suffered the economy of the region. In Iran-Iraq war Iran had US\$ 627 billion and Iraq had US\$ 561 billion economy lost and destruction on large scale but it also affected the economy of the Saudi Arabia who provided US\$ 25 billion of aid to Iraq.

"But this measure by Saudi Arabia did not have a desired impact on Iran because it also cost the Saudi government billions in revenue because oil prices plunged from over $\$ 30$ a barrel to less than $\$ 15$ by the mid 1980s."[19]

In 1980s first time in OPEC history that the price of oil was decreased, less price of oil means less revenue of the oil exporting countries. Iran's economy is the most victim of the deteriorated situation as she faced two decades international sanction on exporting oil, gold and cars.

\subsection{Palestine Israel Conflict}

The most drawback of their rivalry is that Palestine Israel dispute is still unsolved. In the beginning of the dispute under the Egypt nationalist leadership Arabs were active against the Israel which resulted 1948, 1967 and 1973 war in which Israel remained dominant.

Few Arabs countries had started relations with Israel. Now all Muslims countries are busy with their internal, regional and international issues. Syria, Bahrain and Yemen fighting civil war, Iran had nuclear issue and international sanction, Egypt and Iraq have new government after ended regime of Hosni Mubarak in Egypt and Saddam Hussein in Iraq, Jordon, UAE and Saudi Arabia are protecting their monarchies. So Palestinian has no strength from the region in the solution of their issues with Israel.

\section{Conclusion}

Whenever the relations between Iran and Saudi Arabia have been discussed; it is considered as the relations of the two rival forces in the Middle Eastern region, projecting the opposite interests. It is admitted that the root cause of their differences is being the patronage the two different sects of Islam (Sunni and Shia). Most of the followers of both schools of thoughts usually reject the beliefs/doctrine of others. Although both are representing two different ideologies of Islam, however, this cannot be indicated as the only cause of their differences and hostilities for each other. Current research points out five other differences between Iran and Saudi Arabia relationship:

i. Depicting ancient difference on racial basis between Arabs and Persians.

ii. Regional differences between Saudi Arabia and Iran along with their sense of national pride are causing hostility in the region.

iii. System of government in Saudi Arabia is monarchical while in Iran there is an Islamic democracy.

iv. Majority of Saudi Arabian population is Sunni with Wahhabi authority whereas in Iran, there is dominance of Shia doctrine.

v. National language of Saudi Arabia is Arabic while Persian is the official language of Iran.

In current scenario, relations among the state or non state actors on commonalities or differences on the basis of religion, language, caste, creed, culture or social and political system etc does not worth accept national interest. In point of fact, differences on the basis of sect many intensify the existing tense situation but it could hardly initiate antagonism in this regard. For a logical conclusion of the Iran-Saudi Arabia soured relations, if it is said that sect is the root cause of the mistrust and unrest it will not be a rational approach. Two major elements, however, instigated unrest and gulf between their relations.

\section{(1) American involvement:}

Like other major powers of the American authorities are also active to achieve its national interest related to Middle Eastern region. Often the close and trustworthy ties between Iran and Saudi Arabia are not suitable for achieving its required goals in the region. So any positive development between their relations which apparently hit US targets, the American use different tricks to change the peaceful scenario into turmoil, destabilize the political and economic sector. Coup against Iranian Prime minister Mossadagh and the assassination of King Faisal are prominent examples of American involvement in this regard. Similarly, Saudi 
authorities were not ready for American attack on Iraq in 2003, but it was done for the sake of western interests.

\section{(2) Internal policies of both governments:}

On most of the occasions, both governments have adopted such policies which may attract their population, however, set these parties against each other. The Khomeini's remarks about the Saudi Kingdom were the outcome of the Saudi's aid to Iraq against Iran. Similarly, the Hajj Incident of 1987 in which 275 Iranian were died deteriorated already tense situation. It is generally agreed that Khomeini leadership did not promote the sectarianism in the region and work for the unity of the Muslims of the all sects. Remarks against the legitimacy of the Saudi Kingdom; does it means remarks against the Sunni and dominance of Shia?

Yet most of the analysts agreed that the Iranian boogeyman is a useful tool in uniting countries in the Gulf. The Gulf Cooperation Council was essentially started to protect the Arab Gulf states from Iran [20]. During contemporary Israel Hamas conflict, the Iranian President had condemned the Israel suppression on Palestine. However, his remarks against the Israel were taken by Saudi as a threat to the Saudi Kingdom. In presence of hostile policies of Iran, Saudi Kingdom, having insecurity about the survival of its dynastical rule, does not want to lose its leadership in the Muslims world. Saudis, like other Arab countries of the region, are convinced that Iran with an Islamic democracy has a potentical threat to their rule. Consequently, "Saudi Arabia often seems to view the region through sectarian lenses and wants to unite people under the sectarian umbrella of Sunnis. Riyadh therefore views the ascendency of Shias and the war in the region in zero-sum terms."[21] In point of fact, Iran has good relations with other Sunni Arabs countries of the North East Africa but having issues with UAE, Bahrain and Saudi Arabia. However, by taking confidence building measures both major powers of the region can move towards cordial relationship which would ultimately strengthen the peace, security and integrity of the whole region.

\section{References}

[1]. Asia Map-Clickable to Map of Asian Countries, Out of seven world regions, the Arab countries had the lowest freedom score in the late 1990s (UNDP 2002: p. 27).

[2]. Middle East: Land (Scholastic.Com), accessed on, 9-01-2014, available at: www.Scholastic.com/teachers/article/middle-east-land.

[3]. Ibid.

[4]. Ibid

[5]. Abu-Amr, Z. 1993. Hamas: A historical and political background. Journal of Palestine Studies 22:5-19.

[6]. Zubaida, S. 1993. Islam, the People and the State: Political Ideas and Movements in the Middle East, Rev. paperback edition. London: I.B. Tauris 23-41.

[7]. Craig, J. 2001. A life with the Arabs, British Journal of Middle Eastern Studies 28:141- 150 also see Suez Crisis a conflict in the middle east the geopolitical view, accessed on, 15-1-2014, available at: en.org/Wiki/Suez_Crisis.

[8]. Formation of NATO and WARSAW Pact, accessed on, 15-1-2014, available at: www.history.Com/topics/formation-of-nato-andwassaw-pact.

[9]. Zeghal, M. 1999. Religion and politics in Egypt: The Ulema of al-Azahar, radical Islam, and the state (1952-94). International Journal of Middle East Studies 31:371- 399.

[10]. Ibid

[11]. Sadiki, L. 2000. Popular uprisings and Arab democratisation. International Journal of Middle East Studies 32:71-95.

[12]. In the same manner, those trained in classical Arabic were at the time woefully ignorant of the Arabic vernacular (Craig 2001) so that none of the disciplines were equipped to tackle society, culture and religion of the Middle East. Indeed, to anthropologists the very category "Middle East" proved a problematic unit of study, see Gilsenan (1990b). Iran-Saudi Arabia relations- the free encyclopedia, accessed on, 31-12-2013, available at: www.http//- Saudi-Arabia-relations.

[13]. Ibid.

[14]. UNDP. 2002. Arab Human Development Report 2002: Creating Opportunities for Future Generations. New York: United Nations Development Programme (Available: http://www.undp.org/rbas/ahdr/CompleteEnglish.pdf).

[15]. Ibid.

[16]. Iran is taking the region into a new direction and it's time to jump on the opportunity, accessed on, 13-1-2014, available at:

[17]. Zionism and the Shah: on the Iranian elite's evolving perceptions of Israel, accessed on, 14-1-2014, available at: 972mag.com/Zionism-and-the-Shah-on-the-Iranian-elite's-evolving-perceptions-of-Israel.

[18]. Catherine Brown William Dean, UNITED STATES - TURKEY - IRAN, STRATEGIC OPTIONS FOR THE COMING DECADE, September 2011, Institute of Politics Harvard University 79 John F. Kennedy Street, Cambridge, also see Web: www.iop.harvard.edu

[19]. Ibid.

[20]. Rivals-Iran vs. Saudi Arabia - Carnegie Endowment for International Peace, accessed on, 31-12-2013, available at: http//carnegieendowment.org/2011/09/20/rivals-Iran-vs-saudi-arabia/68/g.

[21]. Ibid.

[22]. [PDF] Saudi Arabia and Iran-international Affairs Review, accessed on, 31-12-2013, available at: www.iarwu.org/sites/default/file/articlepdfs/Saudi\%20Arabia \%20and\%Iran.pdf. 